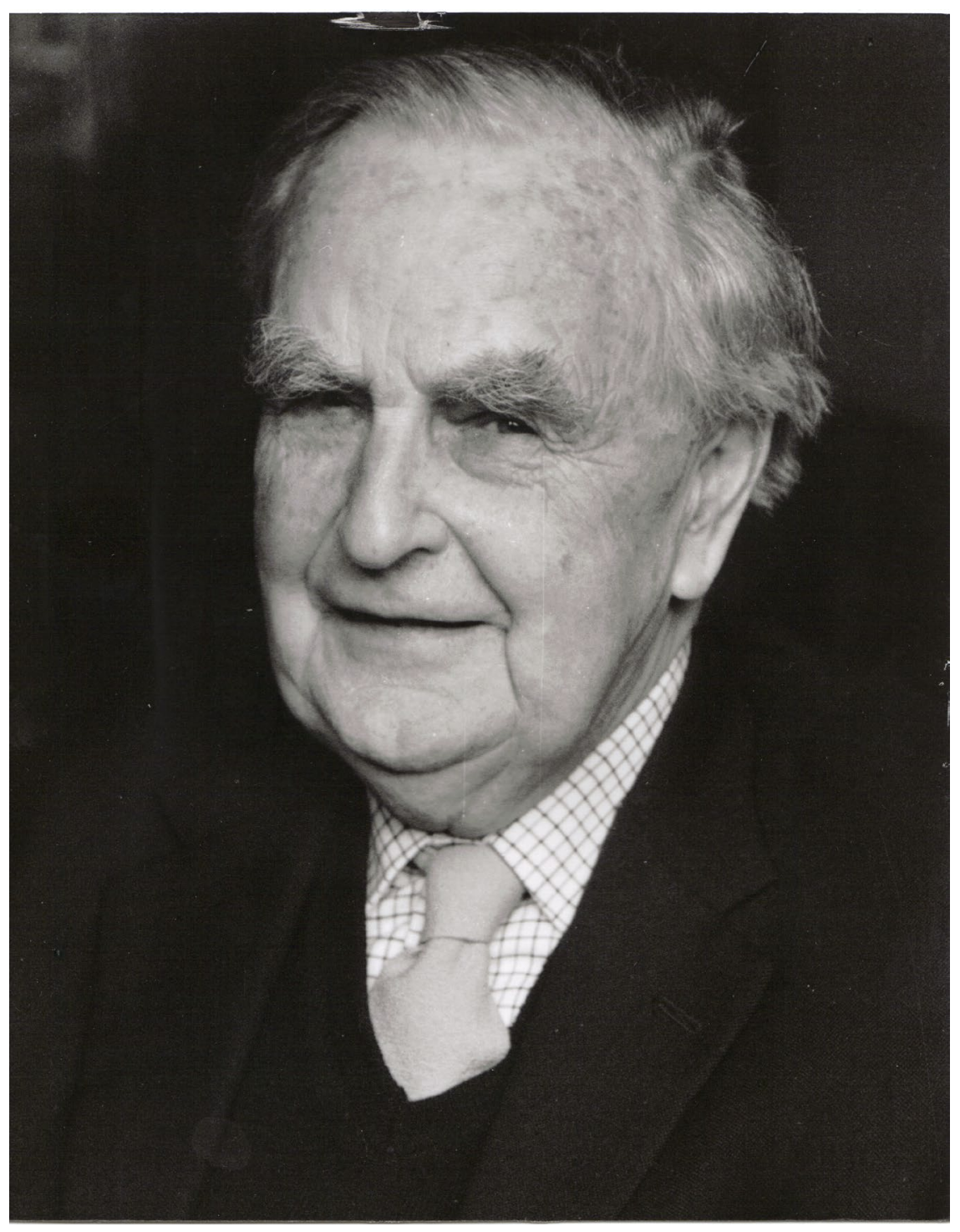

W.S.F. Pickering, 1922-2016. Published with kind permission of John Hardy 


\title{
In Memoriam: W.S.F. Pickering
}

\author{
William Watts Miller
}

William Stuart Frederick Pickering was born on 29 January 1922 in Enfield, London, and died on 23 May 2016 in Coton, Cambridge, where, after a simple but moving service in his local church, St Peter's, he also lies buried. W.S.F. Pickering, as he signed himself in his many publications, but Bill as he was affectionately known to family, friends and colleagues, combined a strong Christian faith and ministry as an Anglican priest with an equally strong devotion to scholarship in his chosen fields of the sociology of religion and of Durkheimian studies, in which he became a leading international authority. In a way, he was highly successful in keeping these commitments separate, in the sense of keeping his faith and his scholarship from obviously and publicly intruding on one another. It is nonetheless clear that their combination meant a lot to him personally, and indeed his social science can be seen as helping to deepen and enlighten his faith. As he explained in the preface to his book Anglo-Catholicism (1989), his youthful piety was replaced by the 'tools of sociology', something that 'proved to be so painful'; yet with pain there can be 'purification', in a critical effort that entails 'a search for basic positions and the raising of fundamental issues'. ${ }^{1}$

\section{Formative Years: 1922-1958}

Bill was the only child of parents who were both practising members of the Church of England. However, he was born at a time when, after the traumas of the Great War, there was a resurgence of various spiritualist and religious movements, including, not least, Anglo-Catholicism. Although he dedicated his book on this movement to the memory of his mother, whose Christian faith 'so much influenced me as a child', he also explained in the preface that as a young boy he visited many churches in and around London with the Anglo-Catholic rituals that increasingly attracted him, and that were 'so much more exciting' than the services at the church his parents attended. 
In any case, the family left London when his father, who worked for the National Provincial Bank, was transferred to a branch in Surrey, where Bill was educated at Surbiton Grammar School, did well in maths and science, and left for a job at his father's bank in the summer of 1939. He was then called up for national service, joined the Royal Air Force and embarked for India, where he worked as a radio mechanic, eventually becoming an instructor. It was during this time that he decided to train, after demobilization, for the church.

He was admitted to King's College London in 1946, graduated as a Bachelor of Divinity in 1949, served the following year with the Sheffield Industrial Mission as well as in the parish of Frodingham, near Scunthorpe, and, after his ordination in 1951, remained there until 1953. He then returned to King's, to combine a teaching post in theology with research for a doctorate in sociology under the supervision of E.O. James, a fellow Anglo-Catholic, ordained priest, and veteran, prolific scholar.

An idea Bill had once entertained was to do a thesis on Kierkegaard, and indeed, at his death, a set of volumes by or about Kierkegaard still occupied a place of honour on his bookshelves. But the idea was very much discouraged by James, who instead urged Bill to do something more modern, up to date and empirical. The British Association for the Study of Religions had just been formed in 1954, with the sixty-six-year-old James as its first president, and with Bill, his last research student, as one of its early supporters. In 1980, in a memoir for the Association, he recorded that it was James who guided him to the sociology of religion, a subject 'virtually unheard of' in England at the time but set 'to be developed in the future'. Like his publications, however, James's influence was no doubt wide-ranging, and, for example, it is apparent from Bill's notes of the many different lecture courses he himself gave over the years that they included a continuing interest in the primitive, prehistoric origins of religion, an interest stimulated by a number of modern discoveries, not least of the caves of Lascaux, opened to the public in 1945. It is also evident from Bill's personal library that it was while working for his doctorate that he began to subscribe to the Archives de sociologie des religions (later the Archives de sciences sociales des religions) and in the process helped to initiate his familiarity with a long-running French tradition in his chosen research field; eventually, moreover, he soon went on to make his own contributions to the Archives, as in an article based on his thesis (Pickering 1961).

In leaving behind his student days in London and going on to serve as a trainee priest in the industrial north, Bill built up a stock of personal skills and experience that was invaluable not only for his ministry but also in doing fieldwork for his thesis. His research focused on a small, traditional working-class community near Sheffield and on the larger, more modern 'boom' town of Scunthorpe, centre of a thriving steel industry. 
He combined the quantitative method of statistical surveys with the more qualitative approach of almost four hundred intense, one-to-one interviews, reported in great detail. It took him from 1953 to 1956 to collect his material, and another two years to write it up into the eight hundred pages or so of his thesis, completed in 1958. It remains unpublished, but, as in a recent study of religion in Britain in the 1950s (Field 2015), has often been drawn on by scholars over the years, and, like Coal Is Our Life (Dennis, Henriques and Slaughter 1956) or The Fishermen (Tunstall 1962), offers a fascinating glimpse of what can now seem a vanished era.

\section{Canada: 1958-1966}

In 1958, the Revd Dr Pickering - as Bill had now become - packed his bags for Canada, to take up an appointment in sociology at St John's College, Winnipeg, an Anglican establishment attached to the University of Manitoba, and like most clerical members of the college faculty in those days, he also worked as a priest, serving at first as chaplain and throughout as lecturer in pastoral theology. The college had only just moved to a new site, and the dean, keen to increase his institution's contribution to the university's undergraduate teaching in the arts and sciences, engaged Bill to initiate a programme of courses in sociology. These were an immediate academic - as well as financial - success, and the course on criminology was a particular triumph, becoming the largest class on that subject in Canada at the time. However, Bill continued to apply himself to the sociology of religion, doing work, for example, on the congregations of some local parishes but also heading a nationwide survey of the clergy of the Anglican Church of Canada, undertaken between 1964 and 1966, and published as Taken for Granted (Pickering and Blanchard 1967). Meanwhile, in an ecumenical but also an enquiring spirit, he had made friends both with Winnipeg's Ukrainian churches and a nearby Hutterite community, resulting in research on this community that eventually became the basis of an article and then of a book (Pickering 1977, 1982).

During his time at St John's, Bill regularly used the summer vacation to see his parents in England but also to go to the continent, especially France, to relax in a country he loved, to pursue his interest in speleology, including, as already mentioned, the caves of Lascaux, and to visit his network of French friends and colleagues. Indeed, because he was so in touch with theological and liturgical developments in France and England, he was an important agent of ideas and practices that were new and at first not always welcome among Anglicans in Canada, but that were nonetheless very much part of how, as a priest, a scholar and an individual, he became a valued member of St John's. 
When he left for England in 1966, it was to fulfil family obligations. He was invited back in 1981 to receive an honorary degree and to deliver a lecture, which he characteristically framed as a question, 'Exit the Sacred?', and which was specially published by the college. He came with his wife Carol, whom he had married three years before, and this was the first of many reunions in Winnipeg with their St John's College friends, who also regularly visited them in England. In 2005, Bill contributed a long memorandum to a committee set up to consider college affairs, and in the course of this remarked that 'my happiest academic days without a shadow of doubt were in London and Winnipeg'. His departure from St John's was greatly regretted by students and staff alike, and a requiem mass for him was held in the college on the same day as his funeral at his home church in Coton.

\section{Newcastle: 1966-1987}

It was not until his return to England that Bill first began to publish on Durkheim, and a set of factors might help with understanding why. It was around this time that a revival of interest in Durkheim took place both in England and in France itself. In England, it involved the long years of research on Durkheim's life and work undertaken by Steven Lukes for an Oxford doctoral thesis, eventually completed in 1968, then published as a highly acclaimed book in 1973. But it also involved the creation of a swathe of new departments of sociology throughout the British university system, together with a demand for courses on Marx/Weber/Durkheim as the discipline's trio of 'founding fathers', and Bill conscientiously made many detailed notes as part of his preparation of lectures on these lines. But his whole engagement with French rather than German social thought clearly picked out Durkheim as the 'founding father' for him to specialize in, and in 1975 he brought out an influential collection of newly translated texts by Durkheim on religion, followed up in 1979 with Durkheim on morals and education. Moreover, another way in which he both drew on and developed a long-running research interest was to bring into the picture figures such as Gaston Richard, a colleague of Durkheim's at Bordeaux who at first collaborated with him but then became a staunch opponent. Thus, the 1975 collection includes a key text by Richard, but also a pioneering note on his life and work, taken up further in a subsequent article devoted to him and his relationship with Durkheim (Pickering 1979b). In turn, all this activity helped to lay the ground for Bill's first major book, Durkheim's Sociology of Religion (1984), a much cited, by now classic reference that established his reputation in the field. 
It seems worth emphasizing, however, that he had by no means decided just to become a Durkheim specialist. On the contrary, he continued to approach the sociology of religion from many angles and through a wide range of concerns. This is evident from his work, already mentioned, on the Hutterites (Pickering 1977, 1982), from articles covering such diverse topics as the 1851 religious census, the modern persistence of rites of passage and the issue of whether or not the sociology of religion undermines religion itself (Pickering 1967, 1974, 1979c), from his collection on the social history of the diocese of Newcastle (Pickering 1981b), but also from the research of one of his postgraduate students on folk religion in a Yorkshire fishing village, published by Cambridge University Press as a book, Between Pulpit and Pew (Clark 1982). Finally, it is important to notice his role in a series of conferences that were held in Oxford and that he helped to organize together with David Martin, an Anglican and professor of sociology at LSE, and John Orme Mills, a Dominican theologian and editor of New Blackfriars.

Beginning in 1978, the conferences explored the relation between sociology and theology and quickly generated an influential edited collection on the issue (Martin, Mills and Pickering 1980). Following on from this success, they were held every year - except in 1982 and 1983 - until a final meeting in 1987. It is clear from Bill's correspondence, as organizing secretary, that the conferences were running out of steam, but also, from expressions of sympathy and concern in letters of colleagues, that he himself was going through a crisis. His mother had been widowed for almost twenty years and they had become very close to one another, but she died towards the end of 1986. Moreover, although he had never been entirely happy in Newcastle, the situation seems to have become worse, judging from correspondence to him, again towards the end of 1986, worrying about 'the diminishing rewards in your work', 'your struggle' and 'despondency'. Just as a form of escape might have been provided by regularly taking breaks away from Newcastle and at his mother's home near Cambridge, the same could be said about his involvement in the conferences at Oxford. In any case, these came to an end in 1987, shortly after his mother's death and shortly before his retirement in the summer of that year. What then appears to have happened is that he found a way to overcome a difficult period for him and, in the process, to reflect on his life and career, by working on a book on Anglo-Catholicism. But apart from the problems this in turn created for him, thanks to the opposition and outrage it stirred up among some of the faithful, its completion in 1989 left open the question of what to do next. It was in this context that he renewed his contacts with Oxford, helped to get going a series of seminars that prepared the ground for a Centre of Durkheimian Studies, and initiated, in 'retirement', the most productive period of his academic life. 


\section{The British Centre for Durkheimian Studies, Oxford: 1991-2014}

The centre was formed in October 1991, with its base in the University of Oxford's Institute of Social and Cultural Anthropology, and with Bill as its organizer, a post he held for well over twenty years until his resignation in November 2014. In reality, however, he was more than just the centre's 'organizer'. He was the driving force of its many-sided activities and programme of seminars, conferences and publications, but also of a whole outlook underlying them.

Thus, it is noticeable that, after Anglo-Catholicism (1989), he continued to publish many single-authored articles (see, for instance, Pickering 1990, 1993a, 1993b, 1993c, through to Pickering 2010, 2014), yet never went on to write, as he could readily have done, any solo books. This was no doubt bound up with his commitment to the centre's programme of seminars, conferences and publications, yet was also a way to encourage, through his own example, the ethos of a collaborative and wide-ranging approach.

In the case of the centre's sponsorship of translations, he was most obviously involved in the organization of a project close to his heart, an English edition of Mauss, On Prayer (2003). He was an important yet discreet influence in the productions, edited, introduced and translated by others, of Hertz, Sin and Expiation (1994), Hubert, Essay on Time (1999), Mauss, The Nature of Sociology (2005) and finally, though not least, Mauss, The Manual of Ethnography (2007), which had also long been a project of Bill's to bring out in English.

Along with these translations, there were also many collections initiated by the centre during the time of his leadership. These included the collections edited by Ken Thompson (1995) on Durkheim, Europe and democracy, by Wendy James and Nick Allen (1998) on Mauss, by Mark Cladis (1999) on Durkheim and Foucault on education and punishment, and by Sondra Hausner (2013) on The Elementary Forms, as well as three collections edited by Bill himself, one of which (Pickering 2000a) provided an invaluable analytical focus on the issue of representations, while another (Pickering 2001) in fact involved his overall coordination of a team co-editing four volumes of critical assessments of Durkheim's work. In addition, he co-edited another seven collections, which started with one on individualism and human rights in the Durkheimian tradition (Pickering and Watts Miller 1993), included two in the same year, one on The Elementary Forms (Allen, Pickering and Watts Miller 1998) along with one on education (Walford and Pickering 1998), and continued this wide-ranging network of interests with a collection on evil and suffering (Pickering and Rosati 2008) and another on the arts (Riley, Pickering and Watts Miller 2013). 
Finally, as far as publications are concerned, it is essential to recognize the role played by Bill, with all his experience, enthusiasm, energy and knowledge, in helping to produce Durkheimian Studies / Études Durkheimiennes. This had roots in a bulletin founded in Paris in the 1970s by Philippe Besnard, subsequently transferring to the United States under the direction of Robert Alun Jones, then moving to Oxford in 1995 and gradually developing as an annual journal. Bill made a key, indispensable contribution not only in undertaking a hefty share of the editorial work but also in preparing the ground for material for the journal and for other publications by the centre in two basic ways, through his organization of its seminars and through his extensive international web of contacts with people in the Durkheimian and related fields.

Year in year out, Bill arranged an annual programme of seminars for the centre from its inception in 1991 all the way through to his resignation in 2014. Although also lending a hand to the centre's conferences during this time, he generally left it to others to take charge of these. In any case, the seminars and conferences were a source not only of much of the material for Durkheimian Studies but also of most of the centre's collections and even of some of its translations, notably the English edition of Mauss, On Prayer. It is possible to note, from the records of these occasions, some of the distinguished international scholars who took part in them, such as Jeffrey Alexander, Jean-Michel Berthelot, Philippe Besnard, Mark Cladis, Jean-Louis Fabiani, Jean-Claude Filloux, Marcel Fournier, David Garland, Maurice Godelier, Alexander Gofman, Hans Joas, Robert Alun Jones, Hans-Peter Müller, Giovanni Paoletti, Massimo Rosati, Warren Schmaus, Dominique Schnapper, Philippe Steiner, Ivan Strenski and Ed Tiryakian. At the same time, the records document the centre's openness over the years to new, upcoming generations of researchers, through discussion of their work in seminars and the opportunity for its publication. Moreover, while resolutely international in its approach, the centre remained distinctively British as a locally embedded habitat, even or especially in its particular ties with the French.

These ties were partly based in Bill's own long association with France, as, for example, in his close personal contacts with Philippe Besnard, who had come over from Paris to Oxford to help to campaign for the centre and take part in the university meeting that decided to initiate it, or again, for instance, in his friendship with Durkheim's grandson, Etienne Halphen (see his tribute to Bill in Halphen 1998), and with Durkheim's great niece, Claudette Kennedy, who had survived Auschwitz and then come to settle in England (see her story in Pickering 2000f and her memories of her great uncle in Kennedy 2010). However, a key role was played by the generosity and support of successive directors of the Maison Française, Oxford, in providing facilities for the centre's seminars and conferences as well as 
accommodation and travel expenses for visiting speakers from France. This relationship got going during the directorship of Maurice Lévy, blossomed under his successor, Jean-Claude Vatin, and involved a formal recognition of the regard for Bill and his achievements when, during the time of Alexis Tadié, he was appointed 'Officier dans l'ordre des Palmes académiques' in a ceremony at the Maison Française in April 2007.

This was just after Bill's eighty-fifth birthday, when he had headed the centre for over fifteen years in a period of intense, continuous, highly productive and creative activity - a sort of non-stop effervescence. Although he tried to keep quiet about the approach of his ninetieth birthday, in January 2012, news leaked out and he was inundated with congratulations and good wishes from colleagues around the world. But ill-health was already beginning to affect his beloved wife, Carol, as well as Bill himself, and the journey from their home in Cambridge to the centre in Oxford became increasingly difficult. Despite these and other problems, the last seminar that Bill organized, in November 2014, was a happy, memorable event. The audience consisted of the centre's traditional, refreshing mixture of different generations as well as of newcomers and stalwarts; papers were given by Rafael Benthien, a young, highly esteemed Brazilian scholar, by Sue Stedman Jones, a longstanding, core member of the centre, and by Philippe Steiner, chair of sociology at the Sorbonne; lunch was generously provided by the Maison Française under its new director, Anne Simonin; Bill, defying his physical frailty, presided over everything with his old energy and sparkle. Above all, however, the occasion captured the whole ethos of the seminars held by the centre down through the years, in a solidarity of scholarship that combined a collegiate atmosphere with informed, lively and indeed often impassioned debate.

It is nonetheless worth re-emphasizing all the behind-the-scenes effort that went into organizing the centre's front-stage activities. It was Bill, for example, who took the lead in negotiating with Marion Berghahn the long and close association with Berghahn Books in producing the centre's publications, just as so much was owed, in the more or less ceaseless task of planning seminars from one year to the next, to Bill's nose for good topics and ability to find an interesting panel of speakers through the grapevine of his extensive personal contacts. In fact, he was a highly social animal who quite liked networking, and enjoyed the distinction of membership of both Wolfson College Cambridge and Wolfson College Oxford. Last but not least, in throwing himself into what amounted to a labour of love, he could depend on the dedication and support of his wife, Carol, who only occasionally complained about being a Durkheim 'widow', and who was a regular, active presence at the seminars, very much helping to create the warmth and friendliness of their atmosphere. 
Carol, two years younger than Bill, was born in 1924 in India, where her parents were American missionaries and where her father became an authority on Indian Islam and published a series of books on it (starting with Titus 1930). Carol herself, although fascinated by a course on Indian sociology that she took before going to college in the States, became disillusioned with the version of sociology she found there and instead took a degree in English and philosophy (see C. Pickering 2004). After the war, she returned to India, where she married Donald Hardy, a civil servant under the Raj, who was later ordained as an Anglican priest and served as rector of Coton, where he died, leaving four sons, Robert, Alan, John and Andrew. John, who also became an Anglican priest, records in a tribute to Bill that with his wedding to Carol he was 'sustained by thirty-seven years of happy marriage and robust relationships with his four stepsons'. One of my own personal memories of Bill is that he frequently recalled Durkheim's attachment to the family, and I have now begun to understand this as an expression of the deep attachment of Bill himself to his home and family life in Coton, even in keeping it discreetly separate, like his faith, from the business of Durkheimian studies.

In general, I have tried to adopt the 'objective' approach of a chronicler of Bill's life and work. But any adequate account of what he achieved in what eventually became his special field needs to bring in more personal and particular impressions. Accordingly, a way to conclude is with some words from one of his French colleagues.

\section{Bill Pickering: A Tribute from Jean-Christophe Marcel}

When I was a young student, I 'fell in love' with Durkheimian sociology and decided to study it, instead of economics. So I read Bill's articles published in volumes edited by Philippe Besnard, and he was one of those I admired and wanted to be like. I remember especially the article about Gaston Richard, 'collaborateur et adversaire', and wondered who Bill Pickering was, and how he could know so much about Richard. I discovered thanks to Besnard this English literature I had been unaware of, especially Bill's books. These readings symbolized, along with those of Willie Watts Miller and Sue Stedman Jones, the common efforts of French and English scholars to reassess Durkheim's thought. It was, for a researcher of my generation, a release and an encouragement to discover this great interest of 'Bill's team' in Durkheim, at a time when he remained discredited in France through the continuing influence of Aron's importation of Weber's sociology. When I 'grew up' and became an academic, I finally met my master Besnard, who agreed to comment on the manuscript I was writing for my 
$\mathrm{PhD}$ dissertation, as well as to be one of the members of the examining jury. I was then duly 'enthroned', and he introduced me to the circle of the British Centre for Durkheimian Studies, after a conference on the centenary of Suicide. So I felt I was accepted in the mythic cluster of European Durkheimologists, among the Études Durkheimiennes founders, and was so proud - a second 'rite of passage', totally enthroned!

The first time I met Bill was at a study day in Oxford. I remember how shy I was, and how he was kind, taking care of me, bringing me to an Indian restaurant and explaining how I could choose different kinds of 'hot' as well as less spicy dishes that we don't have in France. As a beginner, awed at addressing an English audience and allowed to speak in French, I feared the moment when I would have to answer questions. I remember how Bill 'saved my life'. Realizing how tired and stressed I was, in the concentration of following and responding to comments, he cut discussion short, saying, 'I think we will stop, thank you', and preventing Mike Gane from obtaining my answer to his question. I remember my mistake when, on a later occasion, I came in my everyday jeans and shirt but all the other men were in a suit. In the evening, I wanted to 'redeem my offence' and for the surroundings of the dinner we had in a restaurant decided to wear my smartest suit and my tie. But once again I got the dress code wrong; Bill and Willie Watts Miller were wearing casual clothes! I remember Bill's smile. He was discreet and kind.

During another gathering in Oxford, a bust of Durkheim that had been given to the centre was on display and Willie proposed dedicating it to 'our totem: Bill'. We unanimously accepted and applauded the idea. I'll never forget the Durkheimian effervescence around this old and noble man, still working and travelling, keeping 'bon pied bon œil'. I was so happy to communicate with the 'Oxonian Durkheimologists'! I enjoyed these meetings, where, for someone French, the atmosphere was a mix of friendly reunion and serious 'English' academic tradition. One day, Bill offered me the new edition of Mauss's On Prayer in such a kind way that I was very moved.

I also remember Bill coming to France and visiting me at the Sorbonne, as always friendly, with his French béret basque on his head, his mountain walking shoes and his backpack. 'I'm in the Maison Suger', he said, but I didn't dare to ask what this building was, since it seemed to be such an obvious piece of information. The first time he came to my office near the boulevard Raspail, I wanted to be kind and spoke in English. He did the same, speaking French in honour of Durkheim's country. As a result, it was hard to communicate, since my English was poor and his accent sounded strong to my ears. We both laughed and decided, after a while, I should speak French and he should speak English for a better understanding. Later, he was one of the British colleagues I could the most easily hear and understand. We had another interest in common: motorcycles. I used to 
ride a vintage Yamaha that I had to kick to start the engine. Bill was fascinated, fixing his gaze on me and my machine until we disappeared round the corner, and told me how he was also a rider when he was younger. When he emailed, he often asked after my Yamaha; he liked it because, I guess, it was a desert motorcycle - one of the anthropologist's tools?

Bill's death is a great loss for us, as one of the best interpreters of Durkheim, as a wonderful colleague, beloved friend and one of my English 'intellectual godfathers'. We aim at continuing his work to make Durkheimian sociology better known all around the world.

William Watts Miller is editor of Durkheimian Studies / Études Durkheimiennes and a member of the board of the British Centre for Durkheimian Studies, Oxford.

\section{Note}

1. The following account is especially indebted to the Revd John Hardy, Bill's stepson, for a background note on his life and work; to Professor Anthony Waterman, a close friend from his days in Canada, who wrote the memoir circulated at the requiem mass for Bill in Winnipeg and at his funeral in Coton; to Dr Peggy Morgan, former president of the British Association for the Study of Religions, who wrote the obituary of Bill in the BASR Bulletin of November 2016; and to Professor Jean-Christophe Marcel, a longstanding French colleague of Bill's, for a personal tribute.

\section{References}

Allen, N.J., W.S.F. Pickering and W. Watts Miller (eds). 1998. On Durkheim's Elementary Forms of Religious Life. London and New York: Routledge.

Cladis, M.S. (ed.). 1999. Durkheim and Foucault: Perspectives on Education and Punishment. Oxford: Durkheim Press.

Clark, D. 1982. Between Pulpit and Pew: Folk Religion in a North Yorkshire Fishing Village. Cambridge: Cambridge University Press.

Dennis, N., F. Henriques and C. Slaughter. 1956. Coal Is Our Life: An Analysis of a Yorkshire Mining Community. London: Eyre and Spottiswoode.

Field, C. 2015. Britain's Last Religious Revival? Quantifying Belonging, Behaving and Believing in the Long 1950s. Basingstoke: Palgrave Macmillan.

Halphen, É. 1998. Hommages à Émile Durkheim. Oxford: British Centre for Durkheimian Studies.

Hausner, S. (ed.). 2013. Durkheim in Dialogue: A Centenary Celebration of The Elementary Forms of Religious Life. New York and Oxford: Berghahn Books. 
Hertz, R. 1994. Sin and Expiation in Primitive Societies. Ed. and trans. R. Parkin, with a preface by W.S.F. Pickering. Oxford: British Centre for Durkheimian Studies.

Hubert, H. 1999. Essay on Time: A Brief Study of the Representation of Time in Religion and Magic. Ed. R. Parkin, trans. R. Parkin and J. Redding. Oxford: Durkheim Press.

James, W., and N.J. Allen (eds). 1998. Marcel Mauss: A Centenary Tribute. New York and Oxford: Berghahn Books.

Kennedy, C. 2010. 'Personal Recollections of Durkheim, Mauss, the Family and Others', Durkheimian Studies / Études Durkheimiennes 16: 36-56.

Lukes, S. 1973. Émile Durkheim, His Life and Work: A Historical and Critical Study. London: Allen Lane.

Martin, D., J.O. Mills and W.S.F. Pickering (eds). 1980. Sociology and Theology: Alliance and Conflict. Brighton: Harvester Press.

Mauss, M. 2003. On Prayer. Ed. with an introduction by W.S.F. Pickering, trans. S. Leslie. Oxford and New York: Durkheim Press/Berghahn Books.

Mauss, M. 2005. The Nature of Sociology, with an introduction by M. Gane, trans. W. Jeffrey. Oxford and New York: Durkheim Press/Berghahn Books.

Mauss, M. 2007. Manual of Ethnography. Ed. with an introduction by N.J. Allen, trans. D. Lussier. Oxford and New York: Durkheim Press/Berghahn Books.

Pickering, C. 2004. Goodbye India. Privately published.

Pickering, W.S.F. 1958. 'The Place of Religion in the Social Structure of Two Industrial Towns (Rawmarsh, Yorkshire and Scunthorpe, Lincolnshire)', PhD thesis. University of London.

Pickering, W.S.F. 1961. “"Religious Movements” of Church Members in Two Working-Class Towns in England', Archives de sociologie des religions 11: 129-40.

Pickering, W.S.F. 1967. 'The 1851 Religious Census: A Useless Experiment?', British Journal of Sociology 18 (4): 382-407.

Pickering, W.S.F. 1974. 'The Persistence of Rites of Passage: Towards an Explanation', British Journal of Sociology 25 (1): 63-78.

Pickering, W.S.F. (ed.). 1975. Durkheim on Religion: A Selection of Readings with Bibliographies and Introductory Remarks. London: Routledge and Kegan Paul.

Pickering, W.S.F. 1977. 'Hutterites and Problems of Persistence and Social Control in Religious Communities', Archives de sciences sociales des religions 44 (1): 75-92.

Pickering, W.S.F. (ed.). 1979a. Durkheim: Essays on Morals and Education. London: Routledge and Kegan Paul.

Pickering, W.S.F. 1979b. 'Gaston Richard: collaborateur et adversaire', Revue française de sociologie XX: 163-82.

Pickering, W.S.F. 1979c. 'The Sociology of Religion: A Discipline that Undermines Religion?', King's Theological Review 2 (1): 1-7.

Pickering, W.S.F. 1980. 'Edwin Oliver James: Some Personal Reminiscences and Reflections', Bulletin of the British Association for the Study of Religions 31: 7-11.

Pickering, W.S.F. 1981a. Exit the Sacred? Winnipeg: St John's College, University of Manitoba. 
Pickering, W.S.F. (ed.). 1981b. A Social History of the Diocese of Newcastle 18821892. Stocksfield and London: Oriel Press.

Pickering, W.S.F. 1982. The Hutterites: Christians Who Practise a Communal Way of Life. East Grinstead: Ward Lock Educational.

Pickering, W.S.F. 1984. Durkheim's Sociology of Religion: Themes and Theories. London: Routledge and Kegan Paul.

Pickering, W.S.F. 1989. Anglo-Catholicism: A Study in Religious Ambiguity. London: Routledge.

Pickering, W.S.F. 1990. 'The Eternality of the Sacred: Durkheim's Error?' Archives de sciences sociales des religions 69: 91-108.

Pickering, W.S.F. 1993a. 'L'évolution de la religion', in P. Besnard, M. Borlandi and P. Vogt (eds), Division du travail et lien social. La thèse de Durkheim un siècle après. Paris: Presses Universitaires de France, pp. 185-96.

Pickering, W.S.F. 1993b. 'Human Rights and the Cult of the Individual: An Unholy Alliance?’, in Pickering and Watts Miller 1993: 51-76.

Pickering, W.S.F. 1993c. 'The Origins of Conceptual Thinking in Durkheim', in S. Turner (ed.), Émile Durkheim: Sociologist and Moralist. London: Routledge, pp. 52-70.

Pickering, W.S.F. 1994. 'The Enigma of Durkheim’s Jewishness', in Pickering and Martins 1994: 10-39.

Pickering, W.S.F. 1995. Locating the Sacred: Durkheim, Otto and Some Contemporary Ideas. Leeds: British Association for the Study of Religions, Occasional Paper 12.

Pickering, W.S.F. 1998a. 'Mauss's Jewish Background: A Biographical Essay', in James and Allen 1998: 43-60.

Pickering, W.S.F. 1998b. 'The Administration of Punishment in Schools', in Walford and Pickering 1998: 59-71.

Pickering, W.S.F. (ed.). 2000a. Durkheim and Representations. London and New York: Taylor and Francis.

Pickering, W.S.F. 2000b. 'Representations as Understood by Durkheim: An Introductory Sketch', in Pickering 2000a: 11-23.

Pickering, W.S.F. 2000c. 'What Do Representations Represent? The Issue of Reality?' in Pickering 2000a: 98-117.

Pickering, W.S.F. 2000d. 'Reading the Conclusion: Suicide, Morality and Religion', in Pickering and Walford 2000: 66-80.

Pickering, W.S.F. 2000e. 'Durkheim, the Arts and the Moral Sword', Durkheimian Studies / Études Durkheimiennes 6: 43-60.

Pickering, W.S.F. 2000f. 'In Memoriam: Claudette Kennedy', Durkheimian Studies / Études Durkheimiennes 6: 139-40.

Pickering, W.S.F. (ed.). 2001. Émile Durkheim: Critical Assessments of Leading Sociologists, 4 vols. London and New York: Routledge.

Pickering, W.S.F. (ed.). 2002. Durkheim Today. New York and Oxford: Berghahn Books.

Pickering, W.S.F. 2003. 'Does Durkheim Make a Contribution to Understanding One Alleged Cause of Persecution?', Durkheimian Studies / Études Durkheimiennes 9: 40-57. 
Pickering, W.S.F. 2008a. 'The Response of Catholic and Protestant Thinkers to the Work of Émile Durkheim, with Special Reference to Les Formes élémentaires', Durkheimian Studies / Études Durkheimiennes 14: 59-93.

Pickering, W.S.F. 2008b. 'Émile Durkheim', in J. Corrigan (ed.), The Oxford Handbook of Religion and Emotion. Oxford: Oxford University Press, pp. 438-56.

Pickering, W.S.F. 2010. 'Gustave Belot, Critic and Admirer of Durkheim: An Introduction’, Durkheimian Studies / Études Durkheimiennes 16: 109-24.

Pickering, W.S.F. 2014. 'Folklore: A Controversy between Durkheim, Durkheimians and Van Gennep', in Stedman Jones 2014: 131-41.

Pickering, W.S.F., and J.L. Blanchard. 1967. Taken for Granted: A Survey of the Parish Clergy of the Anglican Church of Canada. The General Synod: The Anglican Church of Canada.

Pickering, W.S.F., and H. Martins (eds). 1994. Debating Durkheim. London and New York: Routledge.

Pickering, W.S.F., and M. Rosati (eds). 2008. Suffering and Evil, the Durkheimian Legacy: Essays in Commemoration of the 90th Anniversary of Durkheim's Death. Oxford and New York: Durkheim Press/Berghahn Books.

Pickering, W.S.F., and G. Walford (eds). 2000. Durkheim's Suicide: A Century of Research and Debate. London and New York: Routledge.

Pickering, W.S.F., and W. Watts Miller (eds). 1993. Individualism and Human Rights in the Durkheimian Tradition. Oxford: British Centre for Durkheimian Studies.

Pickering, W.S.F., and W. Watts Miller. 2004. 'A Lost Lecture on Religion', Durkheimian Studies / Études Durkheimiennes 10: 3-9.

Riley, A., W.S.F. Pickering and W. Watts Miller (eds). 2013. Durkheim, the Durkheimians and the Arts. New York and Oxford: Berghahn Books.

Stedman Jones, S. (ed.). 2014. 'Durkheim: Penser pour une nouvelle ère / Durkheim: Thinking for a New Age', special dossier, Europeana 3: 89-199.

Thompson, K. (ed.). 1995. Durkheim, Europe and Democracy. Oxford: British Centre for Durkheimian Studies.

Titus, M. 1930. Indian Islam: A Religious History of Islam in India. London: Oxford University Press.

Tunstall, J. 1962. The Fishermen. London: MacGibbon and Kee.

Walford, G., and W.S.F. Pickering (eds). 1998. Durkheim and Modern Education. London and New York: Routledge. 